\title{
Proximate Composition and Its Seasonality of the Mediterranean Green Crab: Carcinus aestuarii Nardo, 1847 (Brachyura, Portunidae), in Southern Tunisian Waters (Central Mediterranean)
}

\author{
Sonia Baklouti, Abdelkarim Derbali, Khalifa Dhieb, \\ Wassim Kammoun, and Othman Jarboui \\ Institut National des Sciences et Technologies de la Mer (INSTM), BP 1035, 3018 Sfax, Tunisia \\ Correspondence should be addressed to Sonia Baklouti; sonia-baklouti@hotmail.fr
}

Received 12 March 2013; Revised 23 April 2013; Accepted 13 May 2013

Academic Editor: Ricardo Serrão Santos

Copyright (C) 2013 Sonia Baklouti et al. This is an open access article distributed under the Creative Commons Attribution License, which permits unrestricted use, distribution, and reproduction in any medium, provided the original work is properly cited.

\begin{abstract}
The Mediterranean green crab Carcinus aestuarii was recorded in Tunisian waters several years ago. However, since its record in the Gulf of Gabes, no studies have been carried out about the spread of this crab. Because there is a lack of nutritional information concerning this species, this study aimed to characterize the chemical composition of hepatopancreas and gonads of Carcinus aestuarii in view of potential health implication for consumers and to determine the seasonal nutritional quality of females and males taken separately for various size groups. In this study, a total of 1399 individuals were collected along the Sfax coast. The nutritional value of various edible parts of Carcinus aestuarii was evaluated, and gender differences in terms of edible yield and proximate composition, protein, mineral, lipid, and water content, were compared for season, age, and sex. The biochemical compositions were strongly influenced by sex, age, and seasons. The highest protein and lipid contents were detected in gonads and hepatopancreas of females. Autumn was the season with the highest protein content and lowest fat content. Therefore, people with particular diets constrains should consume the ovaries of females in autumn and it should moderate in winter. The hepatopancreas and gonads from Tunisian waters can be a good source of proteins and mineral.
\end{abstract}

\section{Introduction}

It is generally accepted that seafood is important in a healthy, safe, nutritious, and balanced diet [1]. Seafood is an important source of valuable nutrients, like minerals (e.g., calcium, iron, zinc, iodine, selenium, and copper), vitamins, fatty acids (e.g., long chain $\mathrm{n}-3$ polyunsaturated fatty acids) and high quality proteins with essential amino acids, and is low in saturated fats $[2,3]$. Polyunsaturated $n-3$ fatty acids are known to decrease the risks of coronary heart disease and cancer and to improve the response to inflammatory diseases, like eczema, psoriasis, and rheumatoid arthritis [4-6]. However, seafood under certain circumstances poses risks to consumers as it can contain high levels of contaminants (e.g., As, $\mathrm{Hg}, \mathrm{Cd}$, and $\mathrm{Pb}$ ) that either occur naturally or result anthropogenic sources [7].
Crustacean shellfish are also good sources of various minerals and high quality protein [8]. Although the nutritional composition of several commercially harvested species of crab has been partially characterized, shellfish vary widely in their nutrient content [9-11]. The biochemical compositions of different crab species have been reported in various parts of the world $[9,12-15]$. Researchers have also reported differences in concentrations of moisture, fat, ash, protein, and various volatile compounds in meats from different body parts of the blue crab, Callinectes sapidus (Rathbun, 1896), and in the Southeast Asian crab, Charybdis feriatus (Linnaeus, 1758) [16-18]. The first step in exploring the economic potential of the green crab and reports on its proximate, amino acid, and fatty acid compositions was investigated [15]. However, no studies have targeted the proximate composition of the green crab Carcinus aestuarii 


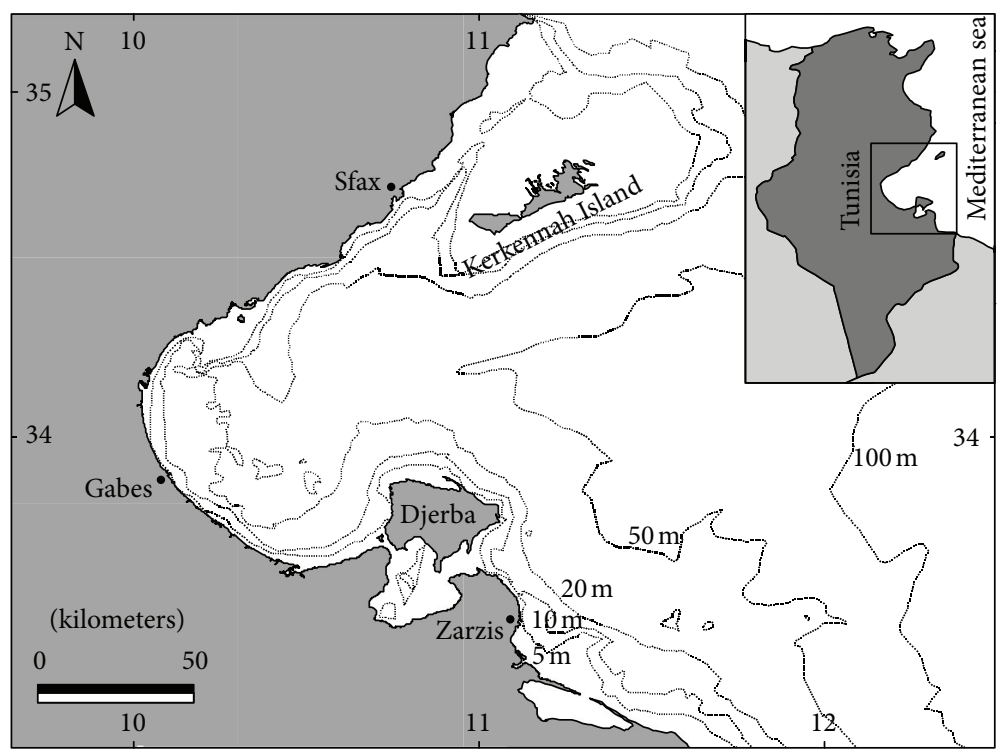

FIGURE 1: Map of the study area, indicating the sampling location (Gulf of Gabes, Tunisia).

(Nardo, 1847) along Tunisian coasts, but instead, findings focused on the fatty composition and nutritional properties of the green crab Carcinus mediterraneus (Czerniavsky, 1884) (= Carcinus aestuarii) [19].

Fundamental knowledge about the nutritional quality of crustaceans and human health implications of its consumption are still lacking, and these would be essential to facilitate the utilization and marketing of this seafood. The purpose of this study was to determine the seasonal nutritional quality of C. aestuarii (Nardo, 1847) in southern Tunisian waters by determining the proximate composition of protein, ash, lipid, carbohydrate, and water of males and females, juvenile and adult. Moreover, considering the controversy of the benefits related to shellfish consumption and the potential impact in consumer's food regarding the different edible tissues and consumption seasonality, samples were taken monthly during one-year period. Data were also analyzed to evaluate the nutritional quality in human consumption by determining the water content, the mineral content, the protein content, and the fat content. Additionally, the human health implications of consuming this species are also discussed.

\section{Material and Methods}

2.1. Study Area. The Gulf of Gabes is located in southern Tunisia and in southern Mediterranean Sea. It extends along $750 \mathrm{~km}$ from La Chebba to the Libyan border (Figure 1). This maritime zone, bathed by Atlantic water masses [20], includes large continental shelves characterized by the presence of large beds of Posidonia oceanica (Delile, 1813) [21-23]. Both wide and shallow continental shelves are topographically regular. The bottom slightly declines towards the sea and $60 \mathrm{~m}$ depth occurs at $110 \mathrm{~km}$ from the coast [22]. The area is locally the most important fishing area and comprises more than $50 \%$ of the Tunisian fishing fleet. The main characteristics of substrates in the Inshore and Midshore areas are muddy sand, being covered in some areas with the seagrass Cymodocea nodosa (Ascherson, 1870) and Zostera noltii (Hornemann, 1832 ) in the first sector and with high cover of seagrass Posidonia oceanica (Delile, 1813) in the second [23]. However, in the deeper waters, the substratum was dominated by coral reefs and dead shells.

2.2. Sampling and Data Analysis. The study involved 1399 individuals of Carcinus aestuarii (881 females and 518 males), collected in the North of Sfax in monthly intervals between September 2008 and August 2009 of total lengths between 22 and $64 \mathrm{~mm}$. For each crab several parameters were recorded: sex, total weight, gonad and hepatopancreas weight, and carapace width and length.

The hepatopancreas and gonads (fresh weight) from each crab were subsequently weighed stored at $105^{\circ} \mathrm{C}$ for $24 \mathrm{~h}$ in an oven [24] and were placed in desiccators to obtain the dry weight for later biochemical analysis.

The moisture, ash, protein, and lipid contents were determined according to the AOAC methodologies [25].

The moisture content was determined by drying the sample in an oven at $105^{\circ} \mathrm{C}$ until a constant weight was obtained. The difference between fresh and dry weights represents the amount of water contained in the product. So this tenor was expressed in $\mathrm{g}$ of water per $100 \mathrm{~g}$ of fresh product by applying the following formula [25]:

$$
\text { moisture content }=\frac{p_{f}-p_{s}}{p_{f}} \times 100,
$$

where $p_{f}$ is fresh weight of the sample and $p_{s}$ is dry weight of the sample.

For mineral content, the ash contained in mineral matter was obtained by calcination of weight dry at $650^{\circ} \mathrm{C}$ for one hour in an oven until all the organic materials were burned and eliminated in volatile form. The ash content was 
expressed in $\mathrm{g}$ of mineral matter per $100 \mathrm{~g}$ of fresh product by applying the following formula [25]:

$$
\text { mineral content }=\frac{p_{1}-p_{0}}{p_{e}} \times 100,
$$

where $p_{0}$ represents the weight after calcinations, $p_{1}$ the dry weight of the sample, and $p_{e}$ is the taken fresh test.

The protein content was determined by the Kjeldahl method [25], and a conversion factor of 6.25 was used to convert total nitrogen to crude protein. This technique has three essential steps that are the mineralization, distillation and dosage

$$
\text { Nitrogen rate }=\frac{14 \times 0.1 \times V}{p_{e}} \times 100,
$$

where 14 represents the molecular weight of nitrogen, 0.1 the normality of the sulphuric acid, $V$ the volume paid in $\mathrm{mL}$ acid, and $p_{e}$ is the mg test.

The fat content was determined by using the Soxhlet extraction method [25], with chloroform as solvent. Indeed, the chloroform compared to petroleum ether and hexane gives the best performance for the extraction of fishery products lipids [25]. This content was expressed in $g$ of fat per $100 \mathrm{~g}$ of fresh product. It was calculated by the following formula:

$$
\text { Fat content }=\frac{p_{1}-p_{0}}{p_{f}} \times 100,
$$

where $p_{0}$ represents the weight of the empty beaker, $p_{1}$ the weight of beaker containing fat, and $p_{f}$ is the fresh weight of the sample.

2.3. Statistical Analyses. All analyses were repeated three times. Results were expressed as mean values \pm standard deviation (SD). The differences were calculated using oneway analysis of variance ANOVA, and statistically significant differences were reported at $P<0.05$.

\section{Results and Discussion}

Biochemical studies are very important from the nutritional point of view. The biochemical constituents in animals are known to vary with season, size of the animal, stage of maturity, temperature, and availability of food, and so forth [26].

In the present study, all examples were captured on the preselected seasons to determine the most appropriate season for utilization. For hepatopancreas and gonads together, the moisture, ash, protein, and fat contents of average were $74.082 \pm 2.709 \%, 14.254 \pm 0.15 \%, 11.514 \pm 0.637 \%$, and $3.548 \pm 0.847 \%$, respectively (Figure 2 ). The results of moisture analysis of European green crab ranged from $79.1 \pm 0.4 \%$ to $82.30 \pm 0.5 \%$. In the crab Carcinus maenas (Linnaeus, 1758), the moisture value was $79.0 \pm 0.7 \%$ [13]. These values are close to findings of the present study. The measures of Blue crab's (Callinectes sapidus, Rathbun, 1896) and sand crab's (Portunus pelagicus, Linnaeus, 1758) breast meat fat contents

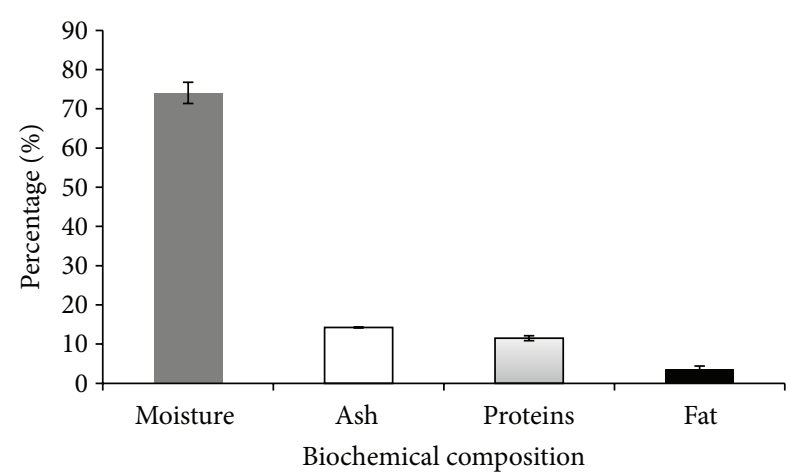

FIGURE 2: The percentage of biochemical composition of hepatopancreas and gonads in Carcinus aestuarii (Nardo, 1847) from the Gulf of Gabes (Tunisia).

were $1.51 \pm 0.01$ and $1.53 \pm 0.01 \%$, respectively [27]. In Northern Canada, the European green crab samples taken from 4 different stations had protein contents of 13\%-14\% [15].

Lipids are highly efficient as sources of energy and they contain more than twice the energy of carbohydrates and proteins [28]. In Podophthalmus vigil (Fabricius, 1798) the lipid values were assessed from $15.13 \%$ to $9.73 \%$ [29]. However, the lipid values recorded in Charybdis smithii (MacLeay, 1838) varied from $6.2 \%$ to $7.6 \%$ [30]. In Chaceon affinis (MilneEdwards \& Bouvier, 1894) the lipid value was 0.7\% [31]; in blue crab it was 1.5\% [32]. On other hand, the lipid content in Scylla serrata (Forsskal, 1775) from body meat was 1.65\% and claw meat was $2.01 \%$ [33]. The lipid values in S. serrata (Forsskal, 1775) from body meat (1.07\%) and claw meat (1\%) were assessed by George and Gopakumar [34]. In Portunus pelagicus (Linnaeus, 1758) the lipid value ranged from 3.3\% to $5.6 \%$, and in Portunus sanguinolentus (Herbst, 1783) it was $3.8 \%$ to $5.5 \%$ [35]. The lipid content in Scylla tranquebarica (Fabricius, 1798) of the body meat (0.9\% to $1.6 \%)$, claw meat (1.83\% to $2.06 \%$ ) and leg meat (1.58\% to $2.08 \%$ ) was estimated by Thirunavukkarasu [36]. In comparison, the lipid content of hard shell crabs Charybdis lucifera (Fabricius, 1758) (1.65\%) was found to be a little bit lower than eyestalk ablated crabs $(1.85 \%)$ [37]. In crustaceans, lipids are not only the principal organic reserve and source of metabolic energy, but also indispensable in maintaining cellular integrity. Lipids as a general rule act as major food reserve along with protein and are subject to periodic fluctuations influenced by environmental variables like temperature [38].

According to proximate chemical composition analysis, there were significant differences in the moisture, protein, ash and fat contents in terms of seasons, ages, and sexes $(P<$ $0.05)$. In the whole, female gonads and hepatopancreas were rich in protein and fat. They showed significantly lower ash and moisture than males (Figure 3). In particular, between adults and juveniles, the moisture and ash contents had no significant differences $(P>0.05)$, but instead the fat and the protein contents were low among adults than juveniles $(P<0.05)$ (Figure 4).

It has been reported that freshwater crab is a good source of protein on different regions of the world [39]. The meat 


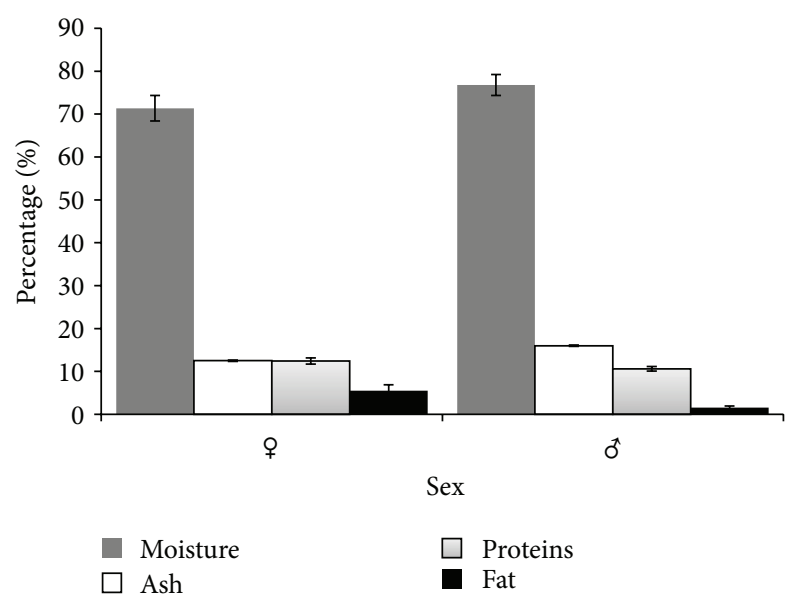

FIGURE 3: Variations of biochemical composition of hepatopancreas and gonads in function of sex in Carcinus aestuarii (Nardo, 1847) from the Gulf of Gabes (Tunisia).

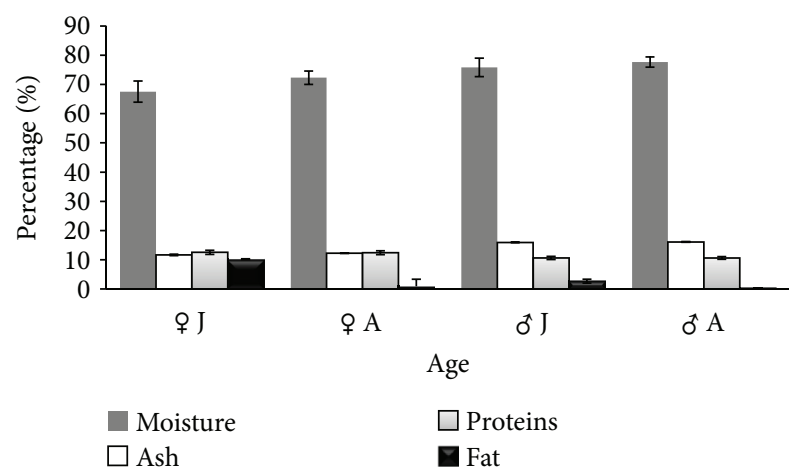

FIGURE 4: Variations of biochemical composition of hepatopancreas and gonads in function of age in Carcinus aestuarii (Nardo, 1847) from the Gulf of Gabes (Tunisia).

protein contents of $P$. pelagicus (Linnaeus, 1758), reported by Türeli et al. [27], were $18.83 \pm 0.23 \%$ and $17.55 \pm 0.23 \%$ in males and females, respectively. In another study, the protein value in P. vigil (Fabricius, 1798) was $15.75 \%$ to $20.16 \%$ [29], and in C. affinins (Milne-Edwards \& Bouvier, 1894) was $17.8 \%$ [31]. In S. serrata (Forsskal, 1775), the protein contents of the body meat and claw meat were $20.11 \%$ and $18.54 \%$, respectively [33]. In blue crab, the protein value was $17.17 \%$ [32]. Indeed, the protein content varied from $0.47 \%$ to $15.91 \%$ in P. pelagicus (Linnaeus, 1758) and from $12.81 \%$ to $13.6 \%$ in $P$. sanguinolentus (Herbst, 1783) [35]. Other studies reported that the protein values in S. serrata (Forsskal, 1775) were $17.69 \%$ and $19.39 \%$ for males and females, respectively [40]. Further investigations reported $11.60 \%$ protein in body meat of males and $19.92 \%$ protein in females body meat of $S$. serrata (Forsskal, 1775) [41]. The chemical composition had variations through seasons (Figure 5). For female juveniles, the highest protein values were shown in autumn and the highest fat values were obtained in winter. Moreover, the lowest protein values were measured during spring while in males the protein values did not vary through seasons

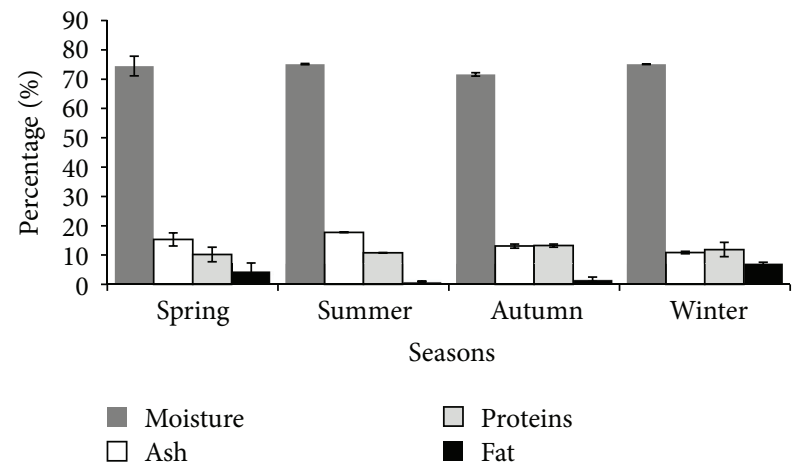

FIgURE 5: Variations of biochemical composition of hepatopancreas and gonads in function of seasons in Carcinus aestuarii (Nardo, 1847) from the Gulf of Gabes (Tunisia).

(Figures 4 and 5). In Potamon potamios (Olivier, 1804) the lowest protein values $(13.94 \pm 0.228 \%)$ were measured in females during spring while in males $(18.35 \pm 0.202 \%)$ during summer [42].

The highest fat values for female and male juveniles showed in winter and spring (Figures 4 and 5). The chemical composition analysis of crab gonads and hepatopancreas revealed variable moisture contents ranging from $60.134 \pm$ 2.174 to $78.998 \pm 4.054 \%$ according to the season, and there was no significant difference between sexes $(P>0.05)$. The highest fat values for females and males juveniles were showed in winter $(10.497 \pm 0.457 \%$ and $3.638 \pm 0.535 \%$, resp.).

Autumn is the best season to eat crab, especially due to the lower fat content and the higher protein content in females adults' gonads and hepatopancreas. Previous findings indicated clearly that C. aestuarii (Nardo, 1847) was beneficial for human health and nutrition, and a preparation of green crab lipids was efficiently hydrolysed by human pancreatic juice in vitro, suggesting a good digestibility of these lipids in vivo [19]. Other studies showed that the protein is essential for the sustenance of life and accordingly exists in the largest quantity of all nutrients as a component of the human body [28].

The present study showed that green crab gonads and hepatopancreas were rich in proteins and poor in fat. Both tissues can be a good source of low fat content. These results are in agreement with those found in the literature for other crustaceans, like blue crab, Swimmer crab, and Chinese mitten crab though generally lower fat in hepatopancreas has been reported.

In conclusion, this study is the first report investigating the nutrient composition of the green crab Carcinus aestuarii in the Gulf of Gabes. The biochemical compositions were strongly influenced by sex, age and seasons. The hepatopancreas and gonads of green crab from Tunisian waters are a good source of proteins and mineral. From the present study, findings may help to determine future quantitative changes indicating trends in the southern Tunisian waters that are exposed to various factors of environmental conditions and human activities. 


\section{Acknowledgments}

This work was undertaken with the aid of funds provided by National Institute of Sciences and Technologies of the Sea (INSTM, Sfax Center). Special thanks go to the technical and supporting staff of INSTM for their practical assistance in sampling and laboratory analysis. The authors thank Farida Ktata, an English teacher at the National School of Engineering of Sfax (ENIS), for proofreading the paper. The authors are also grateful to the anonymous referees whose suggestions and comments improved the submitted paper.

\section{References}

[1] WHO, "Food based dietary guidelines in the World Health Organization European Region. Report EUR/03/5045414," 2003, http://www.who.org.

[2] P. M. Kris-Etherton, W. S. Harris, and L. J. Appel, "Fish consumption, fish oil, omega-3 fatty acids, and cardiovascular disease," Circulation, vol. 106, no. 21, pp. 2747-2757, 2002.

[3] M. C. Nesheim and A. L. Yaktine, Seafood Choices: Balancing Benefits and Risks. Analysis of the Balancing of Benefits and Risks of Seafood Consumption, National Academies Press, Washington, DC, USA, 2007.

[4] A. Gil, "Polyunsaturated fatty acids and inflammatory disease," Biomedical Chromatography, vol. 56, no. 8, pp. 388-396, 2002.

[5] C. E. Roynette, P. C. Calder, Y. M. Dupertuis, and C. Pichard, "n-3 polyunsaturated fatty acids and colon cancer prevention," Clinical Nutrition, vol. 23, no. 2, pp. 139-151, 2004.

[6] C. R. Harper and T. A. Jacobson, "Usefulness of omega-3 fatty acids and the prevention of coronary heart disease," American Journal of Cardiology, vol. 96, no. 11, pp. 1521-1529, 2005.

[7] I. Sioen, J. Van Camp, F. Verdonck et al., "Probabilistic intake assessment of multiple compounds as a tool to quantify the nutritional-toxicological conflict related to seafood consumption," Chemosphere, vol. 71, no. 6, pp. 1056-1066, 2008.

[8] "US Department of Agriculture, Agricultural Research Service. USDA nutrient database for standard reference, Release 13. Nutrient Data Laboratory Home Page," 1999, http://www .nal.usda.gov/fnic/foodcomp.

[9] J. Krzynowek, K. Wiggin, and P. Donahue, "Cholesterol and fatty acid content in three species of crab found in the northwest Atlantic," Journal of Food Science, vol. 47, pp. 1025-1026, 1982.

[10] R. G. Ackman and C. Mc Leod, “Total lipids and nutritionally important fatty acids of some Nova Scotia fish and shellfish food products," Canadian Institute of Food Science and Technology Journal, vol. 21, no. 4, pp. 390-398, 1988.

[11] I. King, M. T. Childs, C. Dorsett, J. G. Ostrander, and E. R. Monsen, "Shellfish: proximate composition, minerals, fatty acids, and sterols," Journal of the American Dietetic Association, vol. 90, no. 5, pp. 677-685, 1990.

[12] P. J. A. Siddiquie, Z. Akbar, and R. Qasim, "Biochemical composition and calorific values of the three edible species of portunid crabs from Karachi," Pakistan Journal of Science, vol. 30, no. 2, pp. 119-121, 1987.

[13] D. I. Skonberg and B. L. Perkins, "Nutrient composition of green crab (Carcinus maenus) leg meat and claw meat," Food Chemistry, vol. 77, no. 4, pp. 401-404, 2002.
[14] G. Chaufan, M. Corvi, A. Armesto, L. C. San Martín de Viale, C. Luquet, and M. C. Ríos de Molina, "Comparison between crab hepatopancreas and rat liver uroporphyrinogen decarboxylase," Comparative Biochemistry and Physiology B, vol. 133, no. 2, pp. 251-256, 2002

[15] M. Naczk, J. Williams, K. Brennan, C. Liyanapathirana, and F. Shahidi, "Compositional characteristics of green crab (Carcinus maenas)," Food Chemistry, vol. 88, no. 3, pp. 429-434, 2004.

[16] K. W. Gates and A. H. Parker, "Characterization of minced meat extracted from Blue crab picking plant by-products," Journal of Food Science, vol. 57, no. 2, pp. 267-270, 1992.

[17] E. Lee, S. P. Meyers, and J. S. Godber, "Minced meat crab cake from Blue crab processing by-products-development and sensory evaluation," Journal of Food Science, vol. 58, no. 1, pp. 99-103, 1993.

[18] H. Y. Chung, "Volatile components in crabmeats of Charybdis feriatus," Journal of Agricultural and Food Chemistry, vol. 47, no. 6, pp. 2280-2287, 1999.

[19] S. Cherif, F. Frikha, Y. Gargouri, and N. Miled, "Fatty acid composition of green crab (Carcinus mediterraneus) from the Tunisian mediterranean coasts," Food Chemistry, vol. 111, no. 4, pp. 930-933, 2008.

[20] W. Brandhorst, "Les conditions du milieu au large de la côte tunisienne," Bulletin De L'Institut National Des Sciences Et Technologies Océanographiques De Pêche Salammbô, vol. 4, pp. 129-220, 1977.

[21] F. Ktari Chakroun and A. Azzouz, "Les fonds chalutables de la région Sud-Est de la Tunisie (Golf de Gabes)," Bulletin De L'Institut National De Zoologie, vol. 2, pp. 155-248, 1971.

[22] S. Ben Othman, Le sud tunisien (Golfe de Gabès), hydrologie, sédimentologie, flore et faune [Thèse de doctorat], Faculté des Sciences de Tunis, Tunis, Tunisia, 1973.

[23] M. Ben Brahim, Contribution à l'étude de la posidonie Posodonia Oceanica sur les îles Kerkennah: çenologie et épithytisme [Ph.D. thesis], Faculté des Sciences de Sfax, Tunis, Tunisia, 2005.

[24] D. Frontier-Abou, Techniques D'étude D'Organismes Marins Et De Farines De Poisson. Composition Globale Et lipides, vol. 13, Documents Scientifiques; Centre de Nosy-Bi; ORSTOM, 1972.

[25] AOAC, Official Methods of Analyses of Association of Analytical Chemist, Washington, DC, USA, 15th edition, 1990.

[26] M. Sudhakar, K. Manivannan, and P. Soundrapandian, "Nutritive value of hard and soft shell crabs of Portunus sanguinolentus (Herbst) centre of advanced study in marine biology, Annamalai University, Parangipettai.608 502, Tamilnadu, India I," Journal of Animal Veterinary Advances, vol. 1, no. 2, pp. 44-48, 2009.

[27] C. Türeli, M. Çelik, and Ü. Erdem, "Comparison of Meat Composition and Yield of Blue Crab (Callinectes sapidus RATHBUN, 1896) and Sand Crab (Portunus pelagicus LINNE, 1758) Caught in Iskenderun Bay, North-East Mediterranean," Turkish Journal of Veterinary and Animal Sciences, vol. 24, no. 3, pp. 195-203, 2000.

[28] M. Okuzumi and T. Fujii, Nutritional and Functional Properties of Squid and Cuttlefish, Japan National Cooperative Association of Squid Processors, Tokyo, Japan, 2000.

[29] C. K. Radhakrishnan and R. Natarajan, "Nutritive value of the crab Podophthalmus vigil (Fabricius)," Fishery Technology, vol. 16, pp. 37-38, 1979. 
[30] C. P. Balasubramanian and C. Suseelan, "Biochemical composition of the deep-water crab Charybdis smithii," Indian Journal Fisheries, vol. 48, no. 3, pp. 333-335, 2001.

[31] P. Vanconcelos and N. R. Braz, "Proximate composition of deepsea crab, Chaceon affinis, from an exploratory fishery off Madera Island (Portugal-Eastern Central Atlantic)," in Proceedings of the Scientific Council Meeting, pp. 1-6, Northwest Atlantic Fisheries Organization; NAFO SCR Doc, 2001.

[32] Anon, Results from the USDA, nutrient database for standard reference crustaceans, Crab. blue, cooked, moist head. Blue crab-nutrition html, pp. 1-3, 1999.

[33] P. N. Prasad and B. Neelakantan, "Proximate and essential amino acid composition in edible crab Scylla serrata," Comparative Physiology and Ecology, vol. 14, pp. 34-37, 1989.

[34] C. George and K. Gopakumar, "Biochemical studies on crab Scylla serrata," Fishery Technology, vol. 24, pp. 57-61, 1987.

[35] C. K. Radhakrishnan, "The eggs of marine crabs-an unexploited resource," ICLARM Quarterly, vol. 23, pp. 4-5, 2000.

[36] N. Thirunavukkarasu, Biology Nutritional evaluation and utilization of mud crab Scylla tranquebarica (Fabricius, 1798) [Ph.D. thesis], Annamalai University, Tamil Nadu, India, 2005.

[37] R. Murugesan, P. Soundarapandian, and K. Manivannan, "Effect of unilateral eyestalk ablation on the biochemical changes of edible portunid crab Charybdis lucifera (Fabricus)," Journal of Fisheries and Aquatic Science, vol. 3, no. 1, pp. 82-86, 2008.

[38] R. Nagabhushanam and V. M. Faroogii, "Mobilization of protein, glycogen and lipid during ovarian maturation in marine crab Scylla serrata (Forskal)," Indian Journal of Marine Science, vol. 11, pp. 184-189, 1982.

[39] D. C. J. Yeo, P. K. L. Ng, N. Cumberlidge, C. Magalhães, S. R. Daniels, and M. R. Campos, "Global diversity of crabs (Crustacea: Decapoda: Brachyura) in freshwater," Hydrobiologia, vol. 595, no. 1, pp. 275-286, 2008.

[40] M. Zafar, M. Z. H. Siddiqui, and M. A. Hoque, "Biochemical composition in Scylla serrata (Forskal) of Chakaria. Sundarban area, Bangladesh," Pakistan Journal of Biological Science, vol. 7, pp. 2182-2186, 2004.

[41] P. A. Khan, Biochemichal composition, minerals (Calcium and iron) and chitin content of two portunid crabs Scylla Serrata Forskal and Portunus pelagicus Linnaeus available in and around the coastal region of Bangladesh [M.S. thesis], Institute Marine Science; Chittagong University, 1992.

[42] Ş. Bilgin and Z. U. C. Fidanbaş, "Nutritional properties of crab (Potamon potamios Olivier, 1804) in the Lake of Eğirdir (Turkey)," Pakistan Veterinary Journal, vol. 31, no. 3, pp. 239243, 2011. 

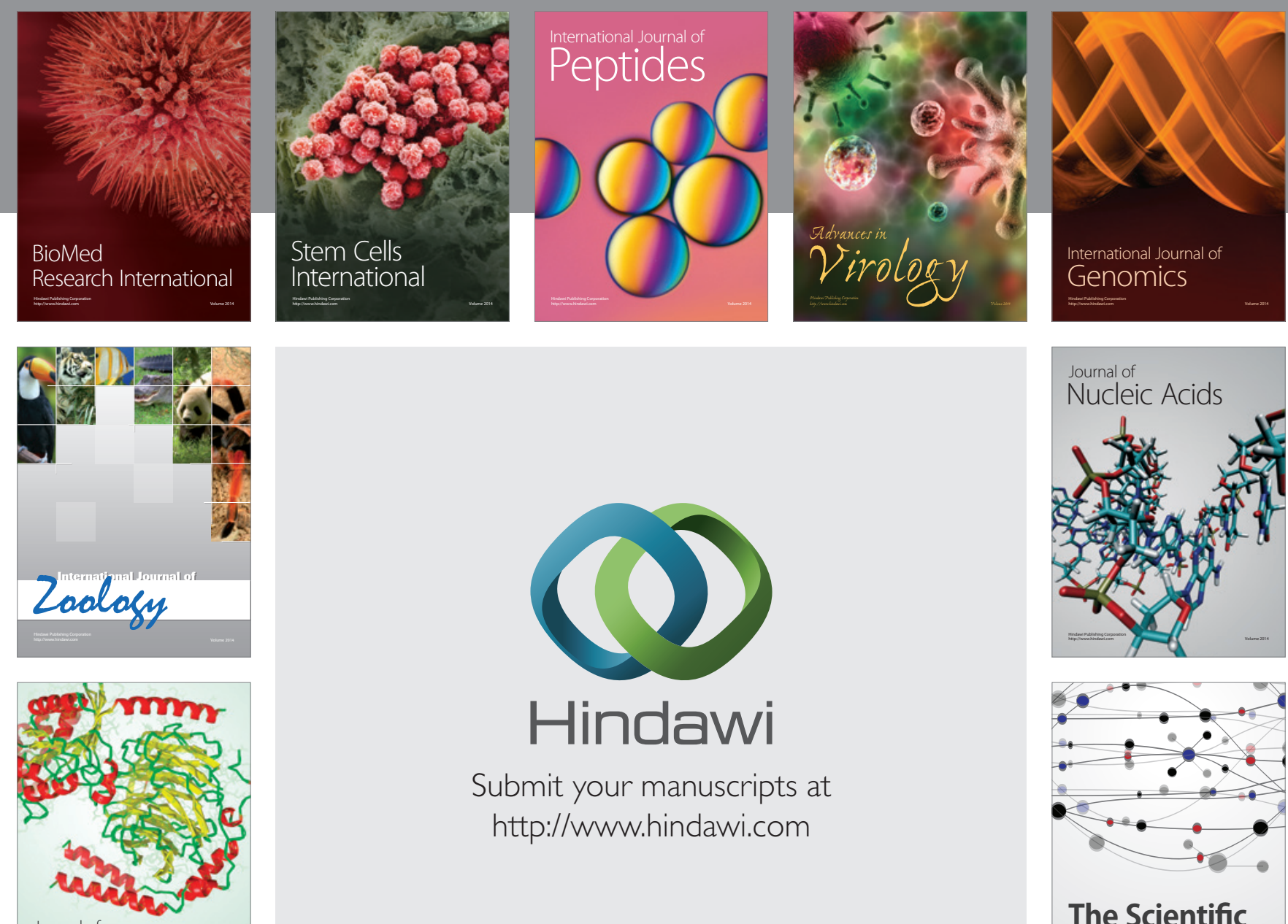

Submit your manuscripts at

http://www.hindawi.com

Journal of
Signal Transduction
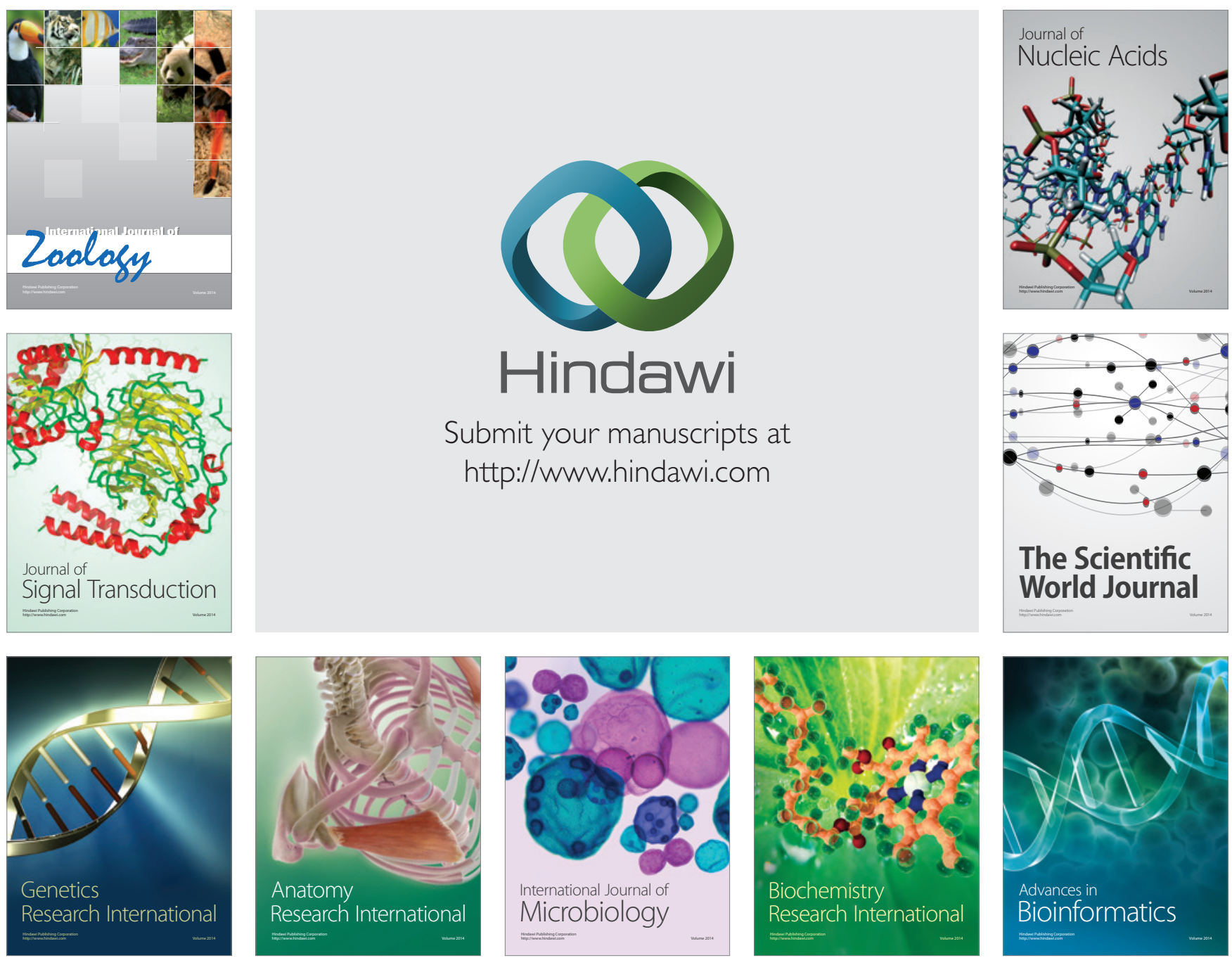

The Scientific World Journal
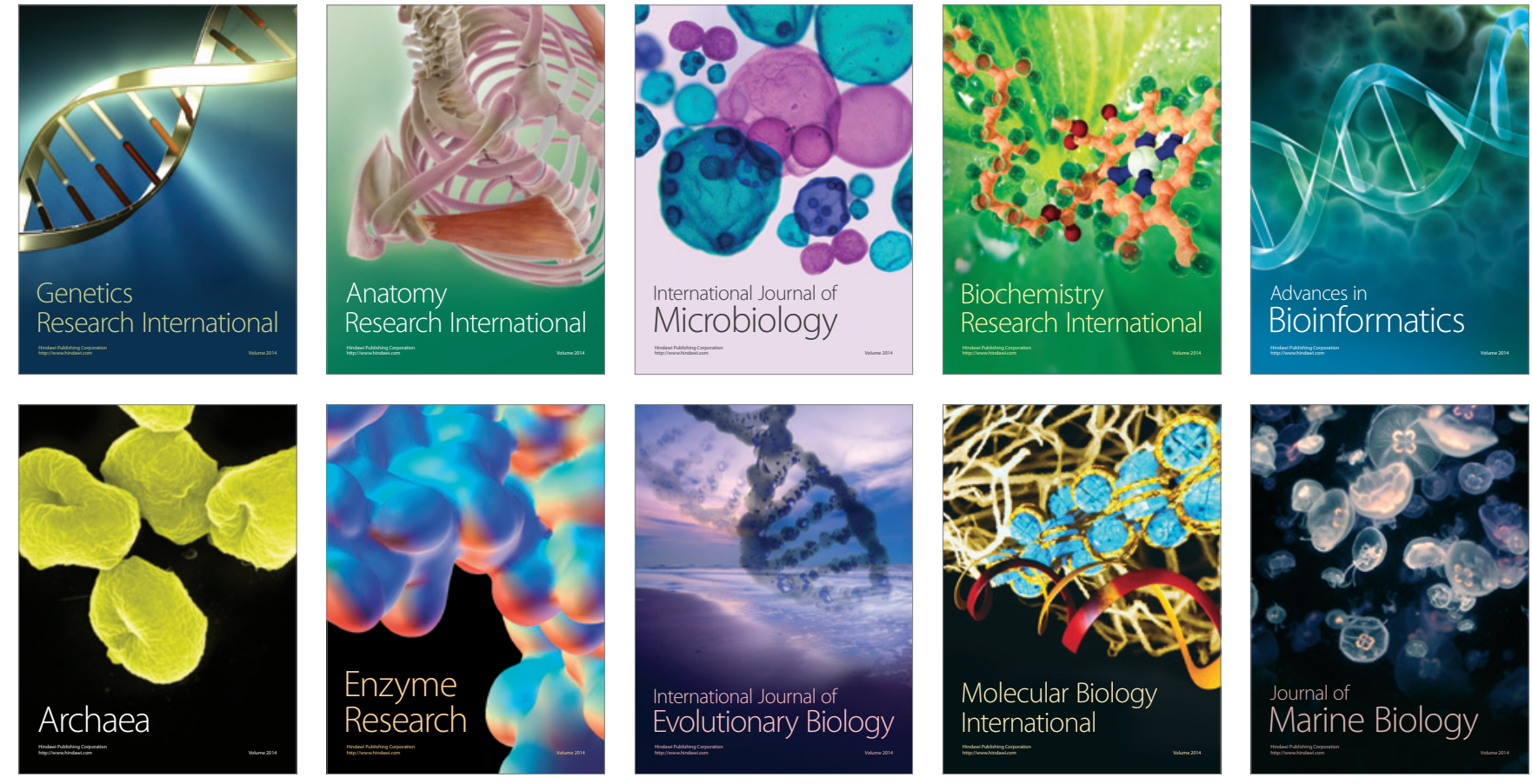